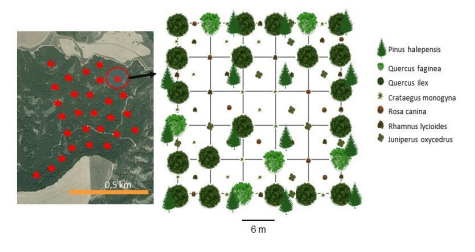

ARTICLE INFO

Citation:

Villar-Salvador P (2016)

Restoration of Spanish pine

plantations: A main challenge for

the 21st century. Reforesta 1: 53 -

66. doi: 10.21750/REFOR.1.04.4

Editor: Steven Grossnickle, Canada

Received: 2016-02-04

Accepted: 2016-04-12

Published: 2016-05-25

This article is Chapter 3 of establishing issue of Reforesta Journal, edited in form of Thematic Proceedings, by Vladan Ivetić and Steven Grossnickle.

Copyright: (C) 2016 Perdo VillarSalvador. This work is licensed under a Creative Commons Attribution-NonCommercialShareAlike 4.0 International License.

\section{Restoration of Spanish pine plantations: A main challenge for the 21st century}

\section{Villar-Salvador Pedro}

Forest Ecology and Restoration Group, Department of Life Sciences, Universidad de Alcalá, 28801 Alcalá de Henares, Spain.

\section{pedro.villar@uah.es}

\begin{abstract}
Most of the Iberian Peninsula has a Mediterranean climate, which strongly determines the objectives, strategies and techniques of forest restoration. This communication addresses a main forest restoration challenge for Mediterranean-climate woodlands in Spain: the transformation of old monospecific pine plantations to more diverse, resistant and resilient forest systems. I also present how afforestation methods and some ideas on plant quality have evolved in the last 80 years. Productivity of Mediterranean forests is low, which discourages private owners to invest in woodland management. Therefore, woodland management strongly relies on public funds. Largescale afforestation in the $20^{\text {th }}$ century has created huge areas of monospecific pine plantations, which have been under thinned and are very simple structurally with almost no understory. The stands are very prone to fires, diseases and drought dieback. However, old pine plantations can facilitate the establishment of late successional trees and shrubs when properly thinned. Therefore, pine plantations are an opportunity for restoring several types of oak-dominated forests at a large scale and resources should invested to preserve and gradually transform these plantations into mixed forests. Funds should be invested in thinning progressively rather than to plant new areas. In many plantations close to oak forests remnants, thinning is the only management required. However, many pine plantations are far from seed sources and enrichment plantations together with thinning are needed. Extensive enrichment plantations are expensive. Therefore, an option is to develop a network of small islets strategically placed inside pine plantations and properly managed as seed foci to foster pine plantation colonization. This option is cheaper than conventional extensive low-density enrichment plantations but research is needed to assess its effectiveness for pine plantation transformation.
\end{abstract}

\section{Keywords}

Afforestation, Biodiversity, Container Stock, Fertilization, Pine Plantations, Oak Stands, Plant Quality 


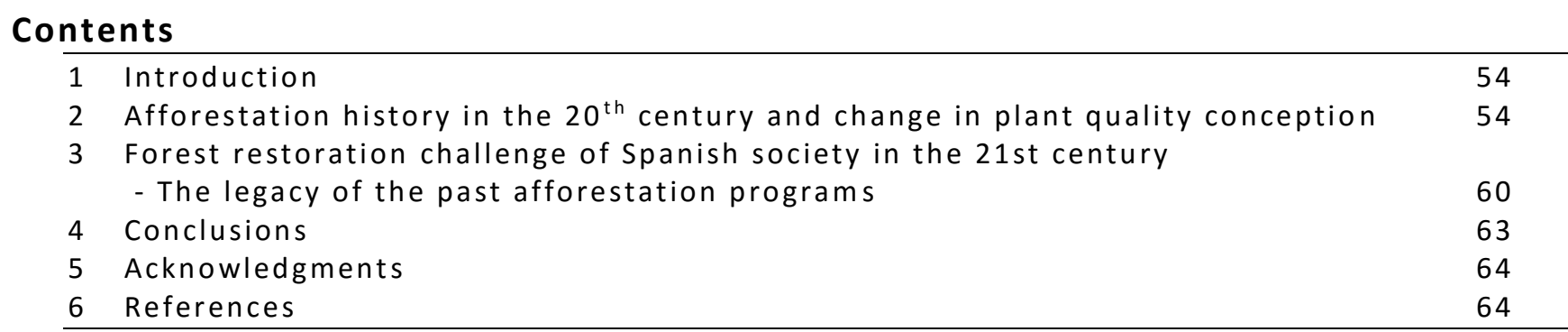

\section{Introduction}

Two thousand years ago the Greek geographer Strabo described the geography and landscape of the Roman Empire (García and Bellido 1945). According to Strabo, the Iberian Peninsula was covered by huge forests. A consequence of the interpretation of Strabo's book was an ancient widespread myth that a squirrel could move from the Pyrenees range in Northern Spain to Gibraltar in the south without descending to the ground. Although this myth has no botanical or ecological basis (Blanco et al. 1998) it suggests the present landscape, in many areas of Spain, is far from removed forested landscapes that likely existed in Roman times. After many centuries of intensive land use, huge sheep livestock raising, forest clearing, wars and ship construction large areas in Iberia became deforested. The paroxysms of this process was achieved in the $19^{\text {th }}$ century where the government expropriated forests of the Catholic Church and sold many public forests to private owners. Around 6-7 million ha were cut (Serrada-Hierro 2000; MAPA 2006). Moreover, population growth expanded cropland at the expense of woodland even on very low productive areas such as steep slopes. Consequently, erosion became a large-scale problem by the end of the $19^{\text {th }}$ century and some estimate that around 17 million ha suffered significant erosion. Landscape in many semiarid regions resembled "badlands" (Fig. 1) and catastrophic floods and landslides were quite common (Machado et al. 2011). All these problems together with the lack of firewood and timber forced the government to implement a huge afforestation program for the next 100 years. The initial objective was the afforestation of 6 million of ha.

This communication addresses the main forest restoration challenge of the Spanish society. This challenge is related to the legacy of the large-scale afforestation programs performed after the Spanish Civil War (SCW). Therefore, I will start describing the characteristics of the afforestation programs emphasizing how methods and some ideas on plant quality have evolved. Around $80 \%$ of the Iberian Peninsula has a Mediterranean climate and only $33 \%$ of Spanish forestland is in the hands of public entities. This imposes specific constraints to the management and dynamics of forest systems. I will focus this communication on Mediterranean forest ecosystems.

\section{Afforestation history in the $20^{\text {th }}$ century and change in plant quality conception}

Before the SCW, afforestation efforts were mostly focused on reducing erosion, mainly in the south and east of Spain (Fig. 1). Less than 72,000 ha were afforested from 1880 to 1936 (Serrada-Hierro 2000), which is small when compared to the afforested area in the following decades. After the SCW in 1939, the government implemented a 
large-scale afforestation program that ended in the mid-1980s. We can distinguish two periods (Fig. 2) that differed in the aims, initial stocking and in the technique used (MAPA 2006).
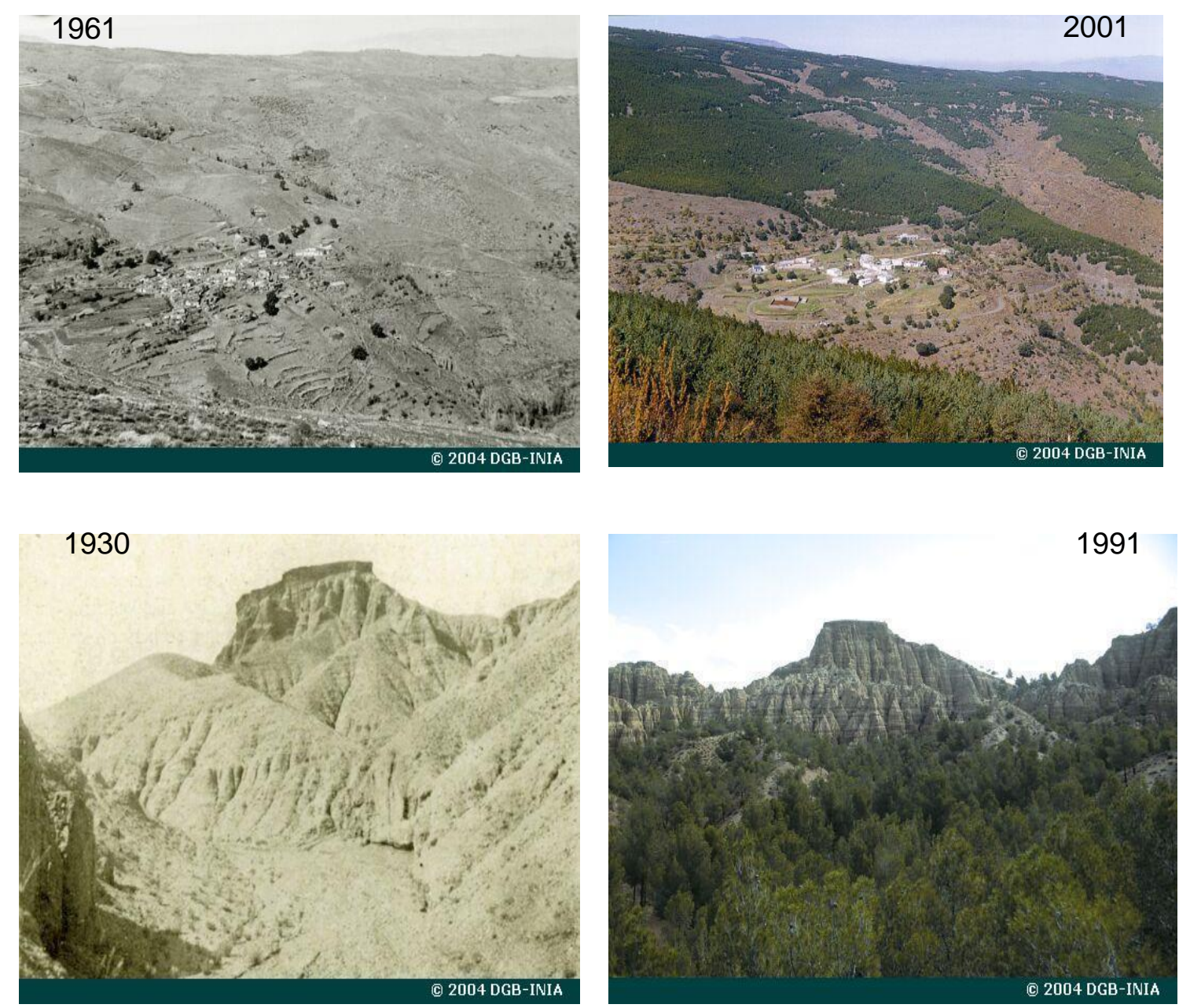

Figure 1. Differences in landscape in two locations in South Eastern Spain before and after afforestation with pine species. Upper pictures are Sierra Filabres (Almería) and lower pictures are Torreón (Granada). Source: Montero et al. 2007.

The first period goes from mid-1940s to early 1960s. The country was devastated and very impoverished after the SCW. The main afforestation goal was improving the economy in rural areas where most Spanish population lived. This consisted of providing jobs to plant trees and the construction of hydraulic structures to stop erosion. Afforestation was mainly carried out by planting bareroot seedlings but direct seeding was also important. Therefore, seed demand was very high. Annual afforested area was very high and in several years, rate was over 100,000 ha per year. Plantation density was very high, frequently higher than 3,000 plants ha ${ }^{-1}$. Seedling establishment was very poor and plants frequently had to be replanted several times to assure stand establishment. No mechanization was used for site preparation, which consisted in hand-made holes or plows pulled by oxen and mules. Main species planted during this period were pines (in decreasing importance, Pinus pinaster, $P$. sylvestris, $P$. halepensis, $P$. nigra and $P$. pinea). 
The second period spans from the early 1960s to mid-1980s. Spain's industry strongly increased and many people moved from the rural areas to the main cities. Consequently, the need to provide employment in rural areas declined quickly after 1960. The aims of the afforestation policy were timber supply and watershed protection, mainly above and around dams. Afforestation rate was lower (Fig. 2) but success in seedling establishment was higher than in the previous period. Site preparation started to be mechanized. Ridges and large terraces, which involved strong soil removal, were the most common site preparation methods in the 1970s. Plantation density decreased relative to the previous period. Plantation was the main afforestation method while direct seeding was minimized. Bareroot seedlings were initially used but they were gradually substituted in the 1970 s by plants cultivated in plastic bags. Main species planted in this period were pines (Pinus pinaster, $P$. sylvestris, P. halepensis, $P$. nigra and $P$. pinea), eucalypts (Eucalyptus camaldulensis in Mediterranean-climate sites) and poplars (mainly Populus $\times$ euramericana hybrids).

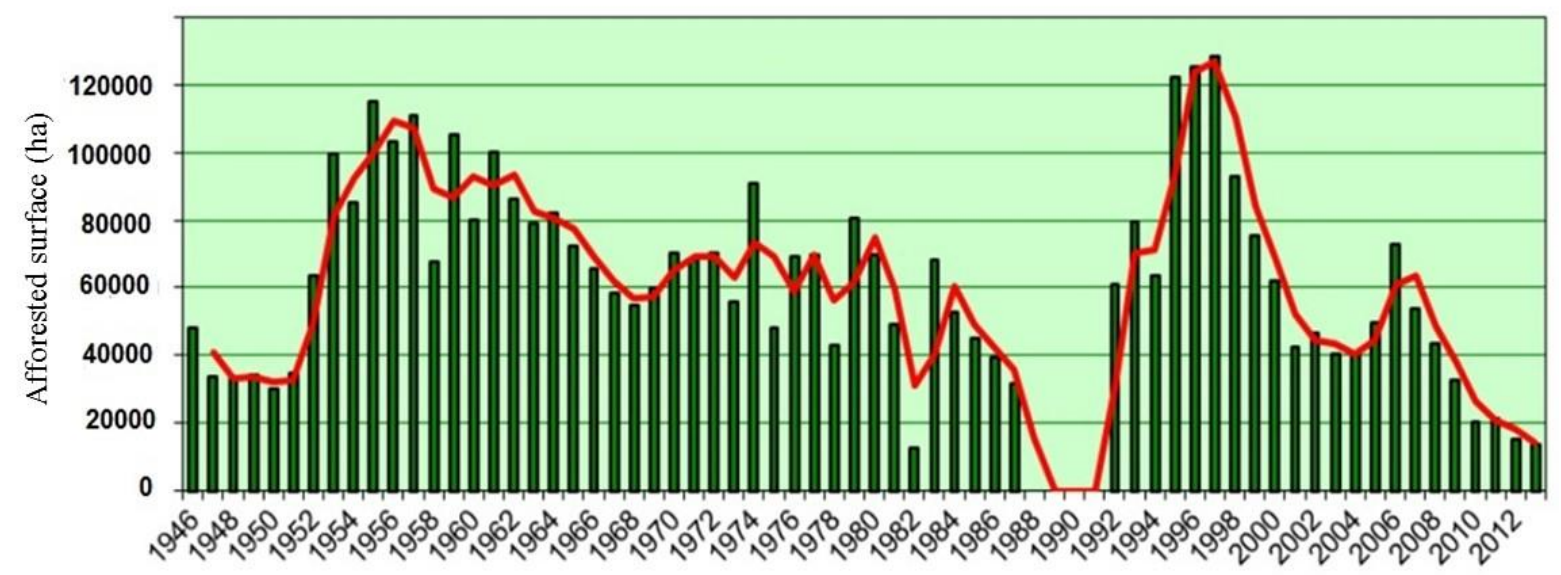

Figure 2. Annual afforested surface in Spain from mid-40s to present (MAGRAMA 2013).

Afforestation ceased in the mid-1980s but in 1993, it resumed at a high rate until to 2008. In this third period, the main aim of the afforestation program was to set aside low productive croplands to reduce the surplus of agricultural products, biodiversity increase in agricultural landscapes and carbon sequestration. The European Union mostly funded the program (MAPA 2006). At present, plantations have been strongly reduced both in cropland and in forestland. The main stock type used in the last 20 years has been $1+0$ and $2+0$ container plant cultivated in 200-300 ml containers and using peat-based or coconut fiber mixes as growing media. Although oaks and pines have been the main planted species, a high diversity of woody plants has been used (Fig. 3) when compared to the previous periods. Demand of native shrubs for mine, quarry and road revegetation is high, which has further stimulated diversification of woody plant production and many nurseries cultivate more than 30 species. Manual soil preparation techniques are avoided not only because yield is lower but also because their effectivity is very low compared to mechanical methods (Bocio et al. 2004). Most common soil preparation methods are subsoiling, holes (Löf et al. 2012) and bench terraces with micro catchments that concentrate runoff into the planting benches (Saquete Ferrándiz et al. 2006). These methods involve minimal soil disturbance and low levels of vegetation removal. 


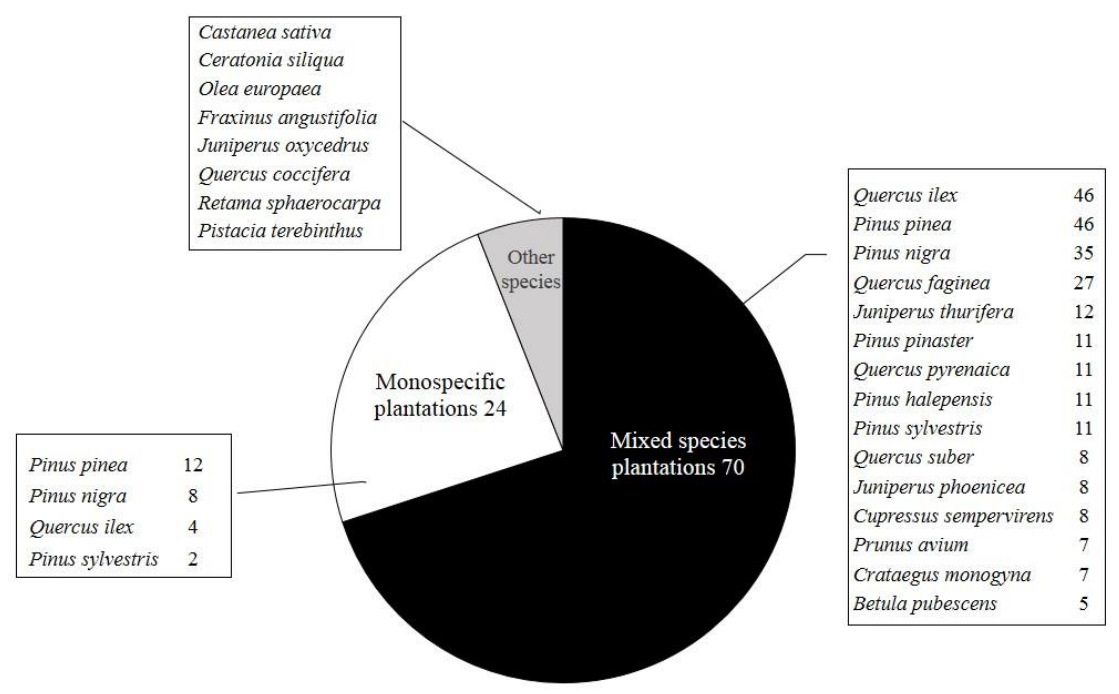

Figure 3. Species used in the afforestation of set aside cropland in 2013. In the mixed species plantations, the figure is the percentage of plots in which each species was planted (MAGRAMA 2013).

Ideas about seedling quality have changed over the last 20 years. The classical paradigm of plant quality in Mediterranean plantations stated that high quality plants should have a xeromorphic structure to perform under drought stress (Fig. 4). This means that plants should have small shoots (low transpiring surface) and high root to shoot ratio (R/S) (Royo et al. 1997). This conception of plant quality probably stemmed from the fact that Mediterranean climate and soils imposes harsh conditions for plant life. The rationale underlying this idea is that xeromorphic-structure plants consume less water than plants with the opposite traits (Lamhamedi et al. 1997; Leiva and FernándezAlés 1998). Therefore, plants were cultivated with low amounts of fertilizer and frequently by restricting irrigation for long periods, which was assumed to enhance plant stress resistance. Minimal fertilization was applied because it was assumed that large plants would increase seedling stress after planting and that fertilization would cause seedling to not be acclimated to nutrient-poor soils. Seedling quality research flourished in Spain from 1993 to 2011 (Tab. 1). Results from these studies caused researchers to revise assumptions about desired seedling attributes.

Very interesting, most studies do not support the classical paradigm on plant quality. Frequently, small plants with high $\mathrm{R} / \mathrm{S}$ and poor fertilized plants (xeromorphic phenotypes) do not have higher performance than plants of the same age but with the opposite traits (productive phenotypes) even under very stressful conditions (Fig. 4B) (for instance Oliet et al. 2005; Cuesta et al. 2010a, 2010b). An analysis of 30 studies on plant quality (Navarro et al. 2006) showed that in $60 \%$ of the cases survival was not related to plant size. Plant size positively explained field survival in $30 \%$ of the cases while in $10 \%$ of the cases small seedlings outperformed large seedlings. Authors concluded that the shoot size standards in several Mediterranean woody trees should be higher than regulated standards in present Spanish legislation. Finally, plant nutrition (mainly nitrogen) proved to be an important issue in explaining out-planting performance in Mediterranean environments (Villar-Salvador et al. 2004a; Oliet et al. 2009, 2013b; Cuesta et al. 2010; Villar-Salvador et al. 2013). 


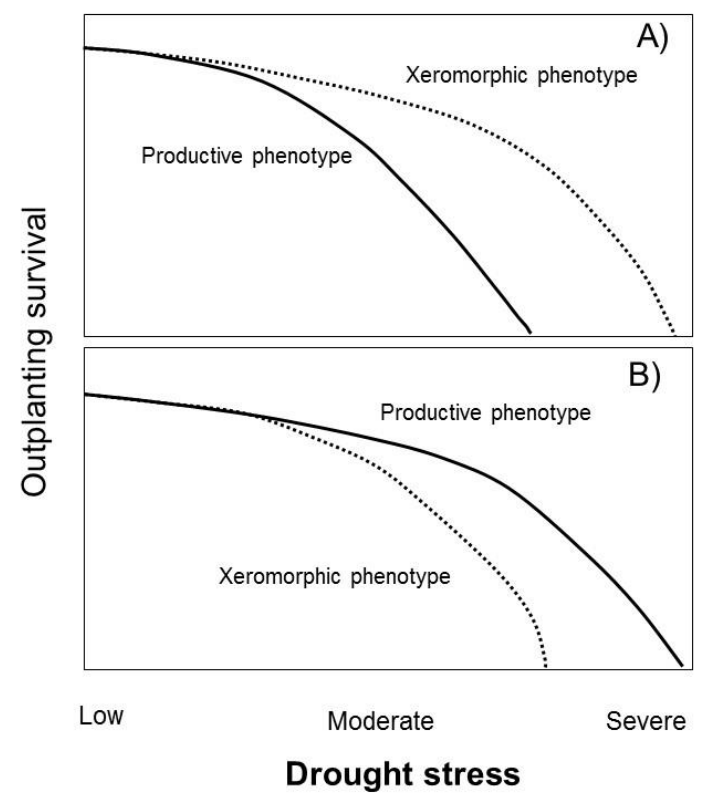

Figure 4. Conceptual model showing the survival of two types of seedlings of contrasting functional attributes (productive and xeromorphic phenotypes) under a drought stress gradient. The upper figure (A) represents the expected survival under the classical paradigm of plant quality (see text) while the lower figure (B) represents the trends observed in research studies in the last 20 years. The productive phenotype refers to plants that, within their maximum growth capacity for a specific age, have large (high mass) shoots, moderate to low root to shoot ratio and high tissue nutrient concentration. The xeromorphic phenotype refers to plants of the same age than productive phenotypes but have the opposite traits (modified from Cuesta 2010).

Table 1. Some papers on plant quality and cultivation of Mediterranean woody species and their main findings.

\begin{tabular}{|c|c|c|}
\hline Studies & Main findings & Species \\
\hline $\begin{array}{l}\text { Peñuelas and Ocaña } \\
1996\end{array}$ & First manual on modern container cultivation of forest species in Spanish & Pinus and Quercus spp. \\
\hline Puértolas et al. 2003 & Nursery fertilization delays cold acclimation & Pinus halepensis \\
\hline $\begin{array}{l}\text { Villar-Salvador et al. } \\
\text { 2004a }\end{array}$ & Moderate and high nursery fertilization increases transplanting performance & Quercus ilex \\
\hline $\begin{array}{l}\text { Villar-Salvador et al. } \\
\text { 2004b }\end{array}$ & $\begin{array}{l}\text { Drought conditioning increases drought tolerance of but has no effect on } \\
\text { transplanting performance }\end{array}$ & Quercus ilex \\
\hline Cortina et al. 2004 & Synthesis on plant quality of Mediterranean forest species & Several species \\
\hline $\begin{array}{l}\text { Dominguez-Lerena et } \\
\text { al. } 2006\end{array}$ & $\begin{array}{l}\text { Analyzes the effect of container characteristics on the nursery and field } \\
\text { performance }\end{array}$ & Pinus pinea \\
\hline Mollá et al. 2006 & Nursery location affects cold acclimation of seedlings & Quercus ilex \\
\hline Chirino et al. 2008 & Deep containers increases physiological quality & Quercus suber \\
\hline Oliet et al. 2009 & High fertilization enhances outplanting performance in the driest site of Europe & Pinus halepensis \\
\hline Luis et al. 2009 & Fertilization increases transplanting performance & Pinus canariensis \\
\hline Palacios et al. 2009 & $\begin{array}{l}\text { The importance of plant quality depends on planting date and site preparation } \\
\text { method }\end{array}$ & Quercus ilex \\
\hline Cuesta et al. 2010a & $\begin{array}{l}\text { Large and nutrient rich seedlings outperform small and nutrient poor plants } \\
\text { under high competition environment }\end{array}$ & $\begin{array}{l}\text { Pinus halepensis and } \\
\text { Quercus ilex }\end{array}$ \\
\hline Cuesta et al. 2010b & $\begin{array}{l}\text { Large seedlings perform better than small seedlings in gaps but not under } \\
\text { shrubs }\end{array}$ & Quercus ilex \\
\hline Andivia et al. 2011 & Fall fertilization enhances seedling performance & Quercus ilex \\
\hline
\end{tabular}


An illustrative example of the outplanting performance differences between the stocktype produced under the classical paradigm and stocktype produced under new cultivation conception was reported by Luis et al. (2009) for Pinus canariensis. This pine is endemic to the Canary Islands and the traditional way for cultivating it was using natural volcanic soil without any fertilization. Seedlings cultivated in this way were small, had low root biomass and mortality after planting in dry sites was very high. Luis et al. (2009) compared this stocktype with and alternative stocktype cultivated in a mixture 2:1 mixture of peat and lapilli amended with slow-release fertilizer, which provided a moderate fertilization. The shoot height and plant mass of the alternative stocktype was 2.5 and 5 times larger, respectively than the traditional stocktype at the end of the cultivation. Annual rainfall and mean annual temperature at the plantation site is 300 $\mathrm{mm}$ and $15^{\circ} \mathrm{C}$, respectively. Two years after planting traditional stocktype had around $35 \%$ less survival and half of the shoot elongation than the alternative stocktype (Fig. 5). Differences in survival between stocktypes were attributed to root growth capacity differences.
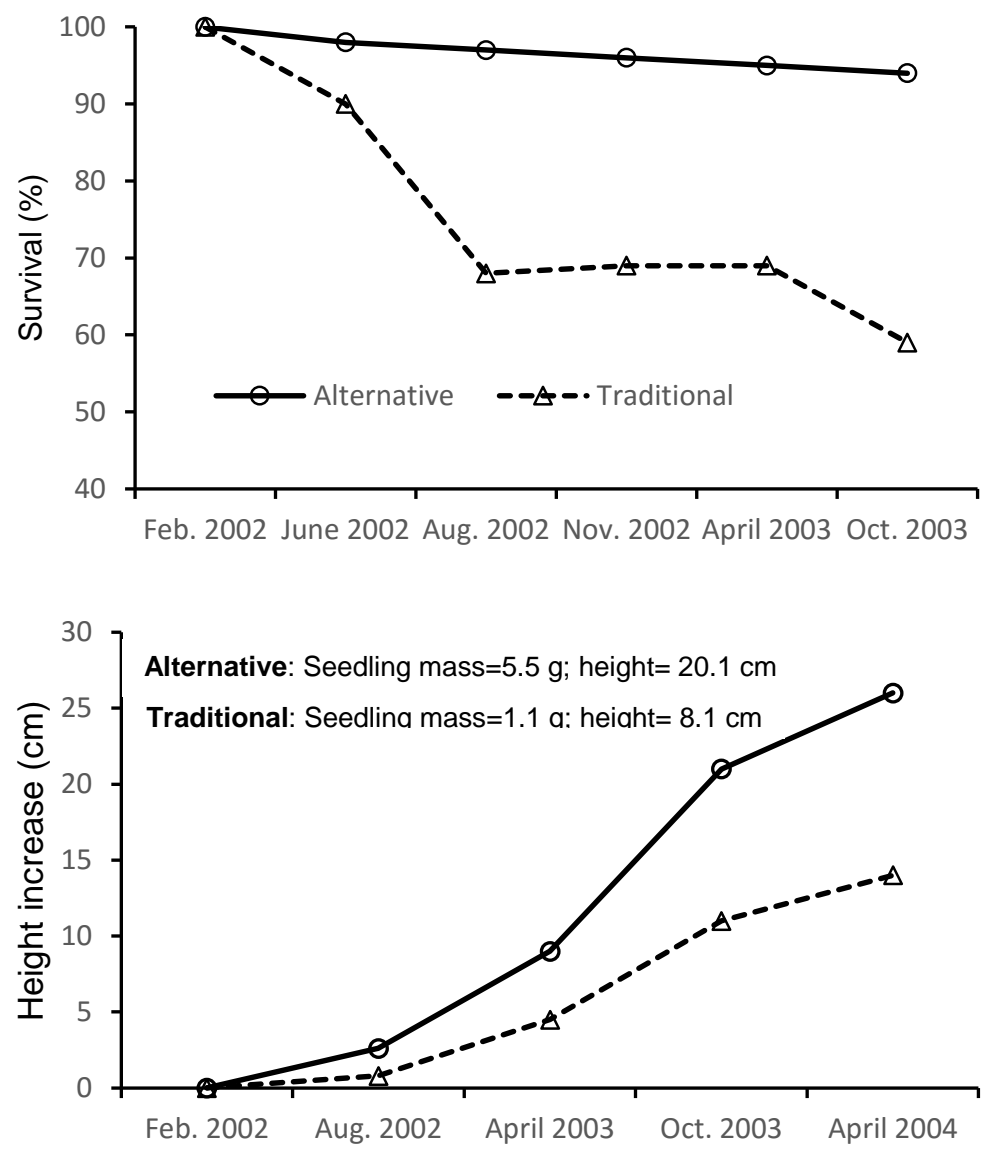

Figure 5. Evolution of survival and shoot growth in two types of Pinus canariensis stocktype in a semiarid planting site. The traditional stocktypes was produced with natural volcanic soil with no fertilization and the alternative stocktype was cultivated in a mixture 2:1 mixture of peat and lapilli amended with slow- release fertilizer. Both stocktypes were cultivated in $308 \mathrm{ml}$ containers. Data inserted in lower figure shows seedling size differences between stocktypes at planting (Modified from data in Luis et al. 2009). 
Experience over the last 20 years caused revisions in the classical seedlingquality paradigm. Part of the paradigm change involved considering in a different way the environment limitations imposed by Mediterranean climate and rethinking the importance of the physiological process underlying seedling establishment (VillarSalvador et al. 2012).

The main limiting period for plantation success in Mediterranean areas is the first summer after planting. Seedling survival to first summer drought is linked to their capacity to avoid water stress that is mainly achieved by having a large, dense and deep root system at the beginning and during the dry season (Grossnickle 2005; Padilla and Pugnaire 2007). Root and shoot growth capacity prior summer drought depends also on the capacity to allocate large amount of carbon, nitrogen and other mineral nutrients to new organ growth during the wet season (Villar-Salvador et al. 2012, 2015). High growth during the wet season is achieved when seedlings can divert large amount of resources to support new root and shoot growth. Functional traits that confer high photosynthesis, nutrient remobilization capacity, and non-structural carbohydrate storage (McPherson and Williams 1998; Dyckmans and Flessa 2001; Millard and Grelet 2010) promote high growth and consequently higher outplanting performance. Some nursery techniques used in producing high quality plants for Mediterranean forest sites are:

Fertilization. Moderate to high fertilization is recommended. Highest transplanting performance is obtained when $\mathrm{N}$ fertilization rate ranges between 70 to $120 \mathrm{mg} \mathrm{plant}^{-1}$ of $\mathrm{N}$ supplied throughout the cultivation season. Most nurseries only use slow release fertilizer or slow release fertilizer combined with direct injection of liquid fertilizers into the irrigation system. Fall fertilization of Mediterranean forest species is a promising fertilization technique to nutrient load seedlings without changing much plant morphology (Oliet et al. 2013). However, it might be useful for species where fertilization does not reactivate shoot elongation in the fall, which can hinder cold acclimation.

Containers. At present, containers volumes used are larger than $200 \mathrm{ml}$. Most Mediterranean species can produce consolidated plugs in containers $>200 \mathrm{ml}$ in one growing season. Container volume positively determines seedling size (DomínguezLerena et al. 2008). Stock cultivated in container volumes of $250-300 \mathrm{ml}$ tend to have high transplanting performance at an acceptable cultivation costs (Puértolas et al. 2012).

Hardening. Plants are grown outdoors under full sunlight for most of the cultivation period. This allows plants to harden in the fall and promote root growth. Some nurseries located in southern Spain shade the plants during the hottest months to reduce water consumption and avoid damage in some shade tolerant species. Reduction of irrigation during the late stages of nursery cultivation (drought hardening) is not a common practice. Nursery location affects seedling hardening and plantations in cold winter locations should be planted with seedlings cultivated in nurseries placed in cold winter sites (Mollá et al. 2006).

\section{Forest restoration challenge of Spanish society in the 21st century - The legacy of the past afforestation programs}

At the end of 2010, more than 4.5 million ha had been afforested since 1940 . Moreover, strong depopulation in rural areas, reduction of farming activities and replacement of firewood by electricity and gas as energy sources have boosted secondary succession or "passive afforestation". Therefore, large areas of abandoned 
pastures and cropland have been colonized by shrubs and forest trees. As a result, there are more forests (and shrublands) than 100 years ago (Montero y Serrada 2013). The landscape has dramatically changed in many places and erosion problems have been strongly reduced (Fig. 1). However, due to the lack of profitability, many pine plantations have never have been thinned or have been under-thinned, resulting in dense $>1,000$ trees $\mathrm{ha}^{-1}$ ) and structurally simple stands. Environmental conditions inside old under thinned pine plantations are very stressful for plant life, resulting in reduced growth of planted trees, and frequently lack of plant recruitment (Pausas et al. 2004). Some consider these stands as "biological deserts". Regardless, the overstocked stands are prone to fire, diseases, and drought dieback (Maestre and Cortina 2004; SánchezSalguero et al. 2013).

In spite of the drawbacks described above, many old pine stands have seedling banks of several trees other than pines that do not thrive into mature trees due to harsh conditions inside the stands. This mainly occurs in stands that are close to patches of forest remnants. After thinning competition is relaxed and facilitation becomes the dominant interaction among pines and other plant species. This boosts the growth of oaks and other mid to late successional woody species such as Juniperus spp., Arbutus unedo, Crataegus monogyna, Rosa spp., Rhamnus spp., Pistacia spp, mostly dispersed by animals, which eventually replace pines (Gómez-Aparicio et al. 2009; Carnicer et al. 2014). Moreover, most colonizing woody species are resprouters, that increase the resilience of pine plantations (Granados et al. 2016). In the absence of pine plantations, oak forests would take many decades if not longer to colonize open areas in many dry areas of southern and central Spain. Consequently, old pine stands can be an opportunity to create mixed forests or to restore other forest systems if they are properly managed. Restoration efforts should concentrate on thinning pine plantations near remnants of woodland. Research is needed to know how large, how many and how far must the patches of forest remnants be to effectively colonize pine plantations. This will help deciding which stands should be primarily thinned. Similarly, we also need to know what are the most effective thinning treatments to facilitate colonization (Granados et al. 2016).

Many pine stands were planted in sites where all previous forest had been extirpated, and at present, there are no seed sources for forest recovery. In these cases, restoration should prioritize the introduction of target forest plants in pine stands. The most common practice to do this is making low-dense extensive enrichment plantations after stand thinning (Granados et al. 2016). Mid to late successional trees and shrubs at low to moderate density are usually used. However, in a socio-economic scenario with little forest restoration funding other "cheaper" restoration strategies should be implemented. One of these strategies is to create small islets of vegetation distributed strategically inside of the pine plantations (Fig. 6). These islets will act as strong seed sources for the colonization of the rest of the plantation if properly managed. This method involves concentrating resources rather than diluting them in space. The method is based on the Maximum Diversity Restoration method (Goosem and Tucker 2013), which was developed for the restoration of rainforest in Northern Australia for sites far from remnant rainforest stands. Similar proposals have been made in other tropical and Mediterranean ecosystems (Rey Benayas et al. 2008; Zahawi and Augspurger 2009; Corbin and Holl 2012).

I propose planting islets of around 0.1 ha in gaps where pines are thinned to $<300$ trees ha-1 to reduce competition for water and nutrients but retaining some shelter 
against high radiation and temperature in summer. Islets should contain 5-7 mid to late successional woody endozoochorous species. One or two species should be structural species in forest communities, such as oaks and the remaining species should be shrubs or small trees common in the understory of oak forests (Fig. 6). Islets would eventually attract animals that consume the fruits and disperse the seeds. Mammals and birds that typically live in croplands usually visit and forage in pine plantations (Sánchez-Oliver et al. 2014).

Effectiveness of this method relies on early and massive seed supply from the islets. This can be accomplished by implementing summer irrigation at planting that will ensure high survival and growth and reduce time to first fruit production. For instance, Quercus ilex takes around 20-30 years to reach sexual maturity under standard Mediterranean conditions. Summer irrigation for three years after planting reduced first reproduction to nine years (Rey Benayas and Camacho-Cruz 2004). However, three irrigation events per year of 20-30 L per plant can cost around 3,000 $€$ ha $^{-1}$ year $^{-1}$ in Spain (Tab. 2). This cost is very high but can be acceptable if concentrated on small areas and it speeds the onset of seed production.
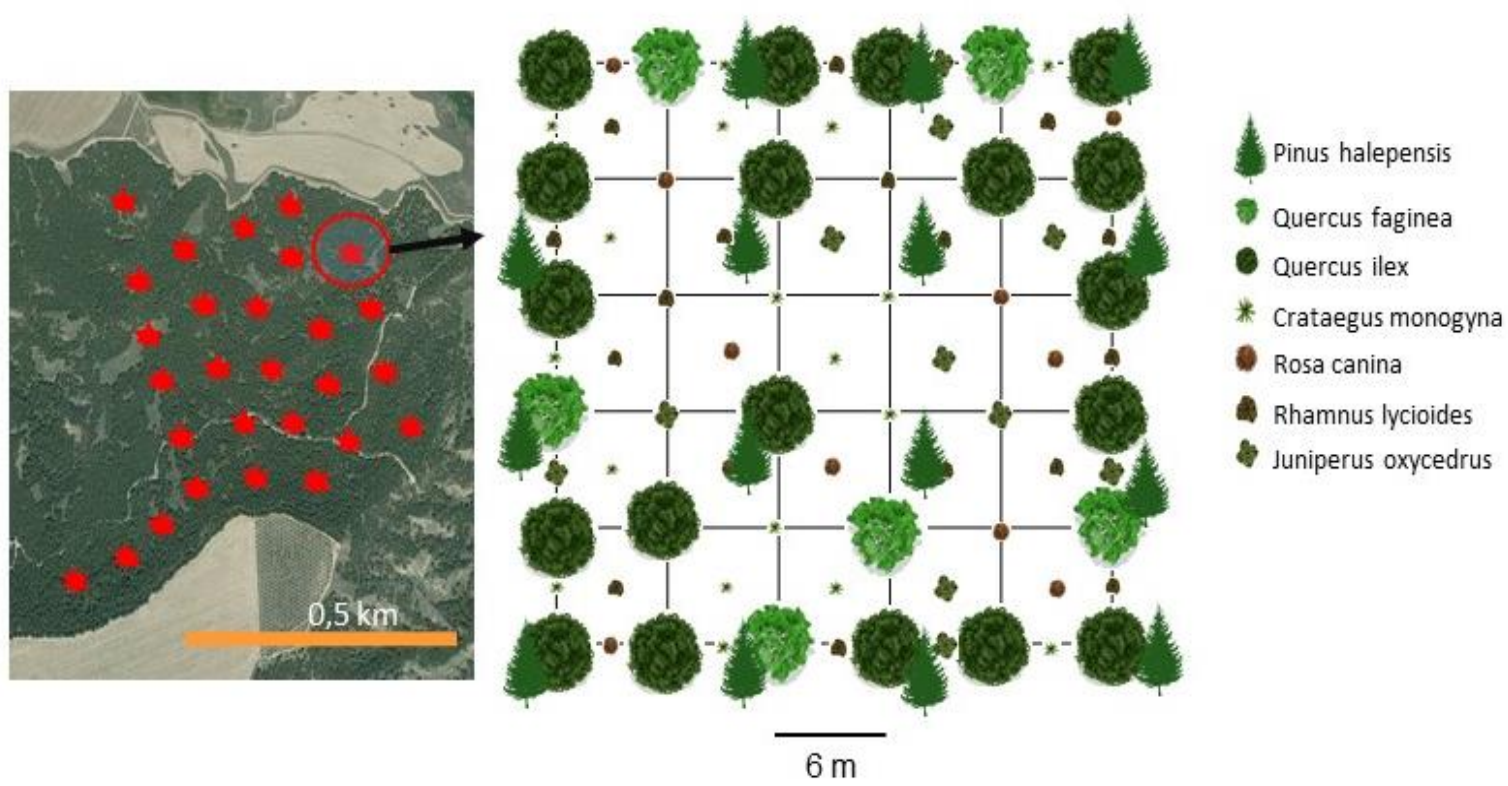

Figure 6. Theoretical outline of the position of islets inside a 50-year-old Pinus halepensis plantation in Alcalá de Henares (Spain) to foster recolonization of the pine stand. Present tree density is 800 trees ha $^{-1}$ and understory is almost inexistent. The closest remnant of natural oak forest is $6 \mathrm{~km}$ away. Islet density is one islet ha-1 and size of each islet is $900 \mathrm{~m}^{2}$. Each islet contains six species, two oak trees and four shrubs that are very common in oak forests of the region. Oak and shrub density in the islet are 270 and 600 plants ha ${ }^{-1}$, respectively.

Once islets start producing seeds, the rest of the pine stand should be thinned to improve regeneration environment. I estimate that the final economic cost of creating islets will be about $40 \%$ lower than extensive enrichment plantations that are not irrigated (Tab. 2). However, the cost effectiveness of this restoration method needs to be tested in Mediterranean environments. Other important questions also remain unanswered. Specifically, it is important to determine spacing among islets, the effective size of islets, and gap size in pine stands and pine density in the gaps. Similarly, we know the additional cost for purchasing a quality seedling. It will therefore be important to determine if higher levels of seedling quality can actually reduce overall costs and speed 
restoration (Puértolas et al. 2012). For instance, we propose the use large oak stocktype cultivated in the nursery in large containers $(0.5-1 \mathrm{~L})$ at high fertilization rates to speed plant growth after planting.

It can be argued that the best option is do nothing and let the pine stands evolve alone. They will progressively transform into oak woodlands or mixed forests in the next 100-200 years, depending on the pine species. However, in my opinion this is not good option because these stands are very prone to fire and diseases that can propagate to other woodland. Probably most of the stands will be destroyed by fire before their transformation. Post-fire pine regeneration often fails, especially in Mediterranean continental climate sites, and this can affect soil protection, one of the main reasons of implementing the huge afforestation program. Finally, high-density stands in dry areas have high transpiration and reduces the amount of underground water and rivers flow (Dye and Versfeld 2007). This is an important issue where water will be a scarcer resource in southern Europe due to predicted climate change. Therefore, it is urgent to accomplish this restoration work. Unfortunately, thinning is expensive and there are no returns if selling thinned trees in Spain at present. While timber price remains low, public institutions should provide most of the resources for old pine plantations restoration.

Table 2. Estimates of the costs of an extensive enrichment plantation (in an old pine plantation) and the cost to create a network of islets inside the forest. Prices represent standard Spanish operational planting and post-planting care costs of sites with an average difficulty. *The planting costs for the islet model are higher because it is assumed that robust, large plants cultivated in large containers will have higher survival. Cost of $2+0$ oak seedlings cultivated in $1.4 \mathrm{~L}$ containers is around $2 €$, while the cost of $1+0$ seedlings is around $0.30-0.40 €$.

\begin{tabular}{ccc}
\hline & $\begin{array}{c}\text { Extensive enrichment } \\
\text { plantation }\end{array}$ & $\begin{array}{c}\text { Establishment of a network of islets } \\
\text { (1 islet ha } \text { }^{-1} \text {; size of each islet is } \mathbf{0 . 0 9} \text { ha) }\end{array}$ \\
\hline Pine plantation area $(\mathrm{ha})$ & 100 & 100 \\
Plant density (plants ha $\left.{ }^{-1}\right)$ & 900 & 900 \\
Planting cost ha ${ }^{-1}(€)$ & 2,500 & $3,500^{*}$ \\
Irrigation cost for three years ha h $^{-1}(€)$ & 0 & 9,000 \\
Thinning cost ha ${ }^{-1}(€)$ & 2,500 & 2,500 \\
Total planted area $(\mathrm{ha})$ & 100 & 9 \\
Total planting cost $(€)$ & 250,000 & 112,500 \\
Total costs of pine plantation transformation & 550,000 & 367,000 \\
\hline
\end{tabular}

\section{Conclusions}

Timber production in most Mediterranean forests is not profitable in the current global economy. In this context, the main objectives of Mediterranean forest management is providing goods such as hunting, mushrooms, tourism or high valuable specific products such as cork and pinyons. Forest management must also ensure valuable ecosystem services such as biodiversity, soil protection, and clean water. Restoration priority should not be afforestation but the transformation of most old pine plantations into more resistant and resilient systems. This involves increasing the structural and functional diversity of plantations, a huge task that must be accomplished with a low level of investment and the disinterest of most private forest owners. This requires prioritizing restoration areas and testing new restoration methods. A restoration option is promoting natural recolonization of old pine stands by (1) thinning 
the old pine stands and (2) concentrating resources to establish small high-diverse vegetation islets as seed foci for the colonization of the rest of the plantation.

\section{Acknowledgments}

I greatly appreciate the organizers of the First International Conference on Restoration Challenges for inviting me as a keynote speaker and making me feel like at home. This communication was supported by the projects Remedinal 3 (S2013/ MAE2719) of the CAM, and CGL2014-53308-P and AGL2011-24296 (ECOLPIN) of the Spanish Government.

\section{References}

Andivia E, Fernández M, Vázquez-Piqué J (2011) Autumn fertilization of Quercus ilex ssp. ballota (Desf.) Samp. nursery seedlings: effects on morpho-physiology and field performance. Ann For Sci 68:543-553.

Blanco E, Casado MA, Costa M, Escribano R, García M, Génova M, Gómez A, Gómez F, Moreno JC, Morla C, Regato P, Sainz H (1998) Los bosques Ibéricos. Una interpretación geobotánica Costa M, Morla C, Sainz H (eds). Editorial Planeta S.A., Barcelona.

Bocio I, Navarro FB, Ripoll MA, Jiménez MN (2004) Holm oak (Quercus rotundifolia Lam.) and Aleppo pine (Pinus halepensis Mill.) response to different soil preparation techniques applied to forestation in abandoned farmland. Ann For Sci 61:171-178.

Carnicer J, Coll M, Pons X, Ninyerola M, Vayreda J, Peñuelas J (2014) Large-scale recruitment limitation in Mediterranean pines: the role of Quercus ilex and forest successional advance as key regional drivers. Glob Ecol Biogeogr 23:371-384.

Chirino E, Vilagrosa A, Hernández EI, Matos A, Vallejo VR (2008) Effects of a deep container on morphofunctional characteristics and root colonization in Quercus suber L. seedlings for reforestation in Mediterranean climate. For Ecol Manage 256:779-785.

Corbin JD, Holl KD (2012) Applied nucleation as a forest restoration strategy. For Ecol Manage 265:37-46.

Cortina J, Bellot J, Vilagrosa A, Caturla RN, Maestre FT, Rubio E, Ortíz de Urbina JM, Bonet A (2004) Restauración en semiárido. In: Vallejo VR, Alloza JA (eds) Avances en el estudio de la gestión del monte mediterráneo. Fundación CEAM, Valencia, pp 345-406.

Cuesta B (2010) Revegetación de campos agrícolas abandonados en ambientes mediterráneos continentales. De la ecofisiología de los individuos a las propiedades ecosistémicas. Ph.D Thesis. Universidad de Alcalá.

Cuesta B, Villar-Salvador P, Puértolas J, Jacobs D, Rey-Benayas JM (2010a) Why do large, nitrogen rich seedlings better resist stressful transplanting conditions? A physiological analysis in two functionally contrasting Mediterranean forest species. For Ecol Manage 260:71-78.

Cuesta B, Villar-Salvador P, Puértolas J, Rey Benayas JM, Michalet R (2010b) Facilitation of oak in Mediterranean shrubland is explained by both direct and indirect interactions mediated by herbs . J Ecol 98:688-697.

Dominguez-Lerena S, Herrero Sierra N, Carrasco Manzano I, Ocaña Bueno L, Peñuelas Rubira JL, Mexal JG (2006) Container characteristics influence Pinus pinea seedling development in the nursery and field. For Ecol Manage 221:63-71.

Dyckmans J, Flessa H (2001) Influence of tree internal N status on uptake and translocation of C and $\mathrm{N}$ in beech: a dual 13C and 15N labeling approach. Tree Physiol 21:395-401.

Dye P, Versfeld D (2007) Managing the hydrological impacts of South African plantation forests: An overview. Forest Ecology and Management 251(1-2), 121-128.

García y Bellido A (1945) España y los españoles hace dos mil años (según la Geografía de Estrabón). Espasa Calpe, Madrid.

Gómez-Aparicio L, Zavala MA, Bonet FJ, Zamora R (2009) Are pine plantations valid tools for restoring Mediterranean forests? An assessment along abiotic and biotic gradients. Ecol Appl 19:2124- 
2141.

Goosem S, Tucker NIJ (2013) Repairing the Rainforest (second edition). Wet Tropics Management Authority and Biotropica Australia Pty. Ltd. Cairns

Granados ME, Vilagrosa A, Chirino E, Vallejo VR (2016) Reforestation with resprouter species to increase diversity and resilience in Mediterranean pine forests. For Ecol Manage 362:231-240.

Grossnickle SC (2005) Importance of root growth in overcoming planting stress. New For 30:273-294.

Lamhamedi MS, Bernier PY, Hébert C (1997) Effect of shoot size on the gas exchange and growth of containerized Picea mariana seedlings under different watering regimes. New For 13:209-223.

Leiva MJ, Fernández-Alés R (1998) Variability in seedling water status during drought within a Quercus ilex subsp. ballota population, and its relation to seedling morphology. For Ecol Manage 111:147156.

Löf M, Dey DC, Navarro RM, Jacobs DF (2012) Mechanical site preparation for forest restoration. New For 43:825-848.

Luis VC, Puértolas J, Climent J, Peters J, González-Rodríguez ÁM, Morales D, Jiménez MS (2009) Nursery fertilization enhances survival and physiological status in Canary Island pine (Pinus canariensis) seedlings planted in a semiarid environment. Eur J For Res 128:221-229.

Machado MJ, Benito G, Barriendos M, Rodrigo FS (2011) 500 Years of rainfall variability and extreme hydrological events in southeastern Spain drylands. J Arid Environ 75:1244-1253.

Maestre FT, Cortina J (2004) Are Pinus halepensis plantations useful as a restoration tool in semiarid Mediterranean areas? For Ecol Manage 198:303-317.

MAGRAMA (2013) Anuario de estadística forestal 2013. Ministerio de Agricultura, Alimentación y Medioambiente. Gobierno de España. Madrid. http://www.magrama.gob.es/es/desarrollorural/estadisticas/forestal anuario 2013.aspx

MAPA (2006) Forestación de tierras agrícolas: análisis de su evolución y contribución a la fijación del carbono y al uso racional de la tierra. Dirección General de Desarrollo Rural, Ministerio de Agricultura, Pesca y Alimentación.Madrid.

McPherson K, Williams K (1998) The role of carbohydrate reserves in the growth resilience and persistence of sabal. Oecologia 117:460-468.

Millard P, Grelet G-A (2010) Nitrogen storage and remobilization by trees: ecophysiological relevance in a changing world. Tree Physilogy 30:1083-1095.

Mollá S, Villar-Salvador P, García-Fayos P, Peñuelas Rubira JL (2006) Physiological and transplanting performance of Quercus ilex L. (holm oak) seedlings grown in nurseries with different winter conditions. For Ecol Manage 237:218-226.

Montero G, Vallejo R, Ruiz-Peinado R (2007) Fototeca Forestal Española, DGB-INIA. Ministerio de Medio Ambiente y Ministerio de Educación y Ciencia. http://www.inia.es/fototeca

Montero G, Serrada R (2013) La situación de los bosques y el sector forestal en España - ISFE 2013. Edit. Sociedad Española de Ciencias Forestales. Lourizán (Pontevedra).

Navarro RM, Villar-Salvador P, del Campo A (2006) Morfología y establecimiento de los plantones. In: Cortina J, Peñuelas JL, Puértolas J, Savé R, Vilagrosa A (eds.). Calidad de planta forestal para la restauración en ambientes mediterráneos degradados. Estado actual de conocimientos. Ministerio de Medio Ambiente, Madrid, pp 67-88.

Oliet J, Planelles R, Artero F, Jacobs D (2005) Nursery fertilization and tree shelters affect long-term field response of Acacia salicina Lindl. planted in mediterranean semiarid conditions. For Ecol Manage 215:339-351.

Oliet J, Planelles R, Artero F, Valverde R, Jacobs D, Segura M (2009) Field performance of Pinus halepensis planted in Mediterranean arid conditions: relative influence of seedling morphology and mineral nutrition. New For 37:313-331.

Oliet JA, Puértolas J, Planelles R, Jacobs DF (2013) Nutrient loading of forest tree seedlings to promote stress resistance and field performance: a Mediterranean perspective. New For 44:649-669.

Padilla FM, Pugnaire FI (2007) Rooting depth and soil moisture control Mediterranean woody seedling survival during drought. Funct Ecol 21:489-495.

Palacios G, Navarro RM, del Campo A, Toral M (2009) Site preparation, stock quality and planting date effect on early establishment of Holm oak (Quercus ilex L.) seedlings. Ecol Eng 35:38-46. 
Pausas JG, Blad C, Valdecantos A, Seva P, Fuentes D, Alloza A, Vilagrosa A, Bautista S, Cortina J, Vallejo R (2004) Pines and oaks in the restoration of Mediterranean landscapes of Spain: New perspectives for an old practice - a review. Plant Ecol 171:209-220.

Peñuelas-Rubira JL, Ocaña-Bueno L (1996) Cultivo de plantas forestales en contenedor - principios y fundamentos. MUNDI-PRENSA, Madrid.

Puértolas J, Gil L, Pardos JA (2003) Effects of nutritional status and seedling size on fiel performance of Pinus halepensis planted on former arable land in th Mediterranean basin. Forestry 76:159-168.

Puértolas J, Jacobs DF, Benito LF, Peñuelas JL (2012) Cost-benefit analysis of different container capacities and fertilization regimes in Pinus stock-type production for forest restoration in dry Mediterranean areas. Ecol Eng 44:210-215.

Rey Benayas JM, Bullock JM, Newton AC (2008) Creating woodland islets to reconcile ecological restoration, conservation, and agricultural land use. Front Ecol Environ 6:329-336.

Rey Benayas JM, Camacho-Cruz A (2004) Performance of Quercus ilex saplings planted in abandoned Mediterranean cropland after long-term interruption of their management. For Ecol Manage 194:223-233.

Royo A, Fernández M, Gil L, González E, Puelles A, Ruano R, Pardos JA (1997) La calidad de la planta de vivero de Pinus halepensis Mill. destinada a repoblación forestal. Tres años de resultados en la Comunidad Valenciana. Montes 50:29-39.

Sánchez-Oliver J, Rey Benayas JM, Carrascal LM (2014) Differential effects of local habitat and landscape characteristics on bird communities in Mediterranean afforestations motivated by the EU Common Agrarian Policy. Eur. J. Wildlife Res. 60: 135-143.

Sánchez-Salguero R, Camarero J., Dobbertin M, Fernández-Cancio A, Vilá-Cabrera A, Manzanedo RD, Zavala MA, Navarro-Cerrillo RM (2013) Contrasting vulnerability and resilience to droughtinduced decline of densely planted vs. natural rear-edge Pinus nigra forests. For Ecol Manage 310:956-967.

Saquete Ferrándiz A, Lledó MJ, Escarré A, Ripoll MA, De Simón E (2006) Effects of site preparation with micro-basins on Pinus halepensis Mill. afforestations in a semiarid ombroclimate. Ann For Sci 63:15-22.

Serrada-Hierro R (2000) Apuntes de repoblaciones forestales. Fundación Conde del Valle de Salazar, Madrid, Spain.

Villar-Salvador P, Peñuelas JL, Nicolás-Peragón JL, Benito LF, Domínguez-Lerena S (2013) Is nitrogen fertilization in the nursery a suitable tool for enhancing the performance of Mediterranean oak plantations? New For 44:733-751.

Villar-Salvador P, Planelles R, Enríquez E, Rubira JP (2004a) Nursery cultivation regimes, plant functional attributes, and field performance relationships in the Mediterranean oak Quercus ilex L. For Ecol Manage 196:257-266.

Villar-Salvador P, Planelles R, Oliet J, Peñuelas-Rubira JL, Jacobs DF, González M (2004b) Drought tolerance and transplanting performance of holm oak (Quercus ilex) seedlings after drought hardening in the nursery. Tree Physiol 24:1147-1155.

Villar-Salvador P, Puértolas J, Cuesta B, Peñuelas JL, Uscola M, Heredia-Guerrero N, Rey Benayas JM (2012) Increase in size and nitrogen concentration enhances seedling survival in Mediterranean plantations. Insights from an ecophysiological conceptual model of plant survival. New For 43:755-770.

Villar-Salvador P, Uscola M, Jacobs DF (2015) The role of stored carbohydrates and nitrogen in the growth and stress tolerance of planted forest trees. New For 46:813-839.

Zahawi ARA, Augspurger CK (2009) Tropical forest restoration: Tree islands as recruitment foci in degraded lands of Honduras. Ecol Appl 16:464-478. 